\title{
Model Pembelajaran Group Investigation (GI) Berbasis Tri Hita Karana Terhadap Hasil Belajar IPA
}

\author{
* Wayan Ardithayasa1, Kadek Yudiana² \\ 12 Program studi Pendidikan Guru Sekolah Dasar, Universitas Pendidikan Ganesha, Singaraja, Indonesia
}

\section{A R T I C L E I N F O}

Article history:

1 Maret 2020 Received in revised form

30 Maret 2020

Accepted 11 April 2020

Available online 15

Mei 2020

Kata Kunci:

GI, Tri Hita Karana,

IPA.

Keywords: GI, Tri Hito

Karana, Natural Science

\begin{abstract}
A B S T R A K
Rendahnya hasil belajar siswa akibat kurang aktifnya siswa mengikuti pembelajan menjdai salah satu alasan penelitian ini dilakukan. Penelitian ini bertujuan untuk mengetahui pengaruh yang signifikan model pembelajaran group investigation (Gl) berbasis tri hita karana terhadap hasil belajar IPA. Penelitian ini merupakan penelitian eksperimen semu (quasi eskperimen) dengan desain non equivalent post test only control group desain. Populasi dalam penelitian ini adalah seluruh siswa kelas V SD jumlah 139 orang. Pengambilan sampel dilakukan dengan teknik simple random sampling. Sampel dalam penelitian ini adalah SD Bayunggede berjumalah 29 orang (ekperimen) dan SD Sekaan berjumlah 25 orang (kontrol). Teknik analisis yang digunakan adalah analisis deskriptif dan uji-t. Hasil perhitungan rata-rata skor hasil belajar IPA siswa yang diberikan perlakuan model pembelajaran group investigation (Gl) berbasis tri hita karana 19,62 termasuk ke kategori sangat baik, sedangkan siswa yang dibelajarkan
\end{abstract} model pembelajaran konvensional memiliki rata-rata skor hasil belajar IPA 15,16 termasuk ke kategori baik. Sehingga berdasarkan temuan tersebut, dapat disimpulkan bahwa model pembelajaran group investigation (GI) berbasis tri hita karana berpengaruh positif terhadap hasil belajar IPA. Model ini bisa dijadikan sebagai pilihan oleh guru digunakan sebagai alternative dalam proses pembelajaran.

\begin{abstract}
A B S T R A C T
The low of the students' learning outcomes was due to the lack of students' participation in the learning process. This problem became one of the reasons why this research was conducted. The aim of this research was to determine the significant effect of group investigation (Gl) based Tri Hita Karana toward the natural science learning outcomes. This research was a quasi-experimental research with a non equivalent post test only control group design. The population in this research was all of fifth grade elementary school students consisted of 139 students. The sampling was taken by using simple random sampling technique. The sample on this research was divided into two groups, such as experimental group consisted of 29 students from Bayunggede elementary school and control group consisted of 25 students from Sekaan elementary school. The analysis technique used descriptive analysis and t-test. The results on the average score of the students who were taught by using the treatment of group investigation (GI) based Tri Hita Karana toward the students' natural science learning outcomes was 19.62 and it was categorize into very good category, while the students who were taught by using conventional had an average score of 15, 16 and it was categorize into good category. So based on these findings, it could be concluded that the group investigation (GI) based Tri Hita Karana had a positive effect on the natural science learning outcomes. This model could be used as an option by other teachers an alternative model in the learning process.
\end{abstract}

\section{Pendahuluan}

Pembelajaran pada dasarnya harus aktif bukan pasif, sehingga keaktifan guru dan siswa sangat diperlukan, guru yang efektif adalah guru yang memberikan siswa pengalaman-pengalaman yang memungkinkan mereka belajar dengan melakukan kegiatan secara langsung (Abdullah, 2017). Pembelajaran yang melakukan kegiatan secara langsung juga ditutut dalam pembelajaran Ilmu pengetahuan Alam (IPA), sebab seperti yang dijelaskan oleh Susanto (dalam Widiartini, Putra, \& Manuaba,

Copyright (C) Universitas Pendidikan Ganesha. All rights reserved 
2019) IPA adalah sebuah usaha manusia memahami alam melalui pengamatan, observasi dan dijelaskan dengan penalaran sehingga mendapatkan suatu kesimpulan. Sedang Menurut Lestari, Ayub, \& Hikmawati (2016) Ilmu Pengetahuan Alam merupakan sekumpulan ilmu-ilmu yang berupaya menjelaskan setiap fenomena atau peristiwa-peristiwa yang terjadi di alam. Sehingga dengan adanya IPA yang merupakan ilmu tentang usaha manusia memahami alam tentang perisiwa atau fenomena alam yang terjadi dengan observasi dan eksperimen perlu adanya pembelajaran IPA yang tepat.

Menurut Lestari et al. (2016) pembelajaran IPA yang tepat yaitu pembelajaran yang mampu mengembangkan sikap ilmiah peserta didik dan tidak hanya menuntut untuk lebih banyak mempelajari konsep-konsep dan prinsip-prinsip sains secara verbalitas, hafalan, pengenalan rumus-rumus, dan pengenalan istilah-istilah melalui serangkaian latihan secara verbal, namun hendaknya dalam pembelajaran IPA, guru lebih banyak memberikan pengalaman kepada siswa untuk lebih mengerti dan membimbing siswa agar dapat menggunakan pengetahuan tersebut dalam kehidupan sehari-hari. Dan menurut Widiartini et al. (2019) Pembelajaran IPA perlu memperhatikan karakteristik siswa yang senang bermain, senang bekerja dalam kelompok, dan senang merasakan atau melakukan sesuatu secara langsung, sehingga tujuan pembelajaran yang tercapai sesuai harapan. Namun kenyataanya pembelajaran IPA selama ini adalah pembelajaran yang kurang memperhatikan suasana menyenangkan bagi siswa, kondisi pembelajaran yang kaku dan tidak memperhatikan karakteristik siswa, sehingga mengakibatkan terpengaruhnya hasil belajar siswa (Kristinawati, Akbar, \& Mahanal, 2017). Terpengaruhnya hasil belajar siswa dapat buktikan dari hasil laporan Programme for International Student Assessment (PISA) 2018 yang dirilis oleh Organisation for Economic Co-Operation and Development (OECD) dipublikasikan oleh Jayani (2019) yang menyatakan Indonesia berada di peringkat 71 dari 78 negara. Serta menyatakan kemampuan siswa masih dibawah rata-rata pada bidang sains. Kenyataan dari hasil PISA 2018 juga terjadi di SD Gugus III Kecamatan Kintamani, Kabupaten Bangli.

Berdasarkan hasil wawancara, observasi, dan pencatatan dokumen yang dilakukan di SD Gugus III Kecamatan Kintamani, Kabupaten Bangli, pada tanggal 19 dan 21 Oktober 2019 didapatkan hasil wawancara dengan guru kelas V yang berada di Gugus III Kecamatan Kintamani, Kabupaten Bangli sebagai berikut: (1) beberapa siswa masih kurang aktif dalam proses pembelajaran, (2) siswa cendrung kurang kosentrasi dan bosan dengan pembelajaran yang diberikan yang selalu di dalam kelas.

Hal ini juga didukung berdasarkan hasil observasi dengan mengamati langsung proses pembelajaran di kelas ditemukan bahwa (1) saat melaksanakan persembahyangan siswa masih sering bermain, (2) kurangnya rasa kepedulian terhadap teman dan kebersihan kelas, dan (3) kurangnya pendidik mengaitkan pembelajaran yang dilaksanakan dengan lingkungan peserta didik dan mempadukan pengalaman yang dimiliki peserta didik, Serta dengan pencatatan dokumen didapatkan nilai Ulangan Tengah Semester (UTS) siswa kelas V Semester I pada mata pelajaran IPA masih kurang optimal yang sebagian besar masih dibawah Kriteria Ketuntasan Minimal (KKM) pada mata pelajaran IPA. Adapun hasil pencatatan dokumen hasil UTS siswa kelas V semester I di Gugus III Kecamatan Kintamani disajikan dalam tabel 01 berikut.

Tabel 01. Nilai UTS IPA Siswa di Gugus III Kintamani

\begin{tabular}{ccccccc}
\hline No & Nama Sekolah & $\begin{array}{c}\text { Jumlah } \\
\text { Siswa }\end{array}$ & KKM & $\begin{array}{c}\text { Nilai Rata- } \\
\text { rata Kelas }\end{array}$ & $\begin{array}{c}\text { Siswa yang } \\
\text { Mencapai KKM }\end{array}$ & $\begin{array}{c}\text { Siswa yang } \\
\text { Belum } \\
\text { mencapai KKM }\end{array}$ \\
\hline 1 & SDN Abuan & 17 & 75 & 68,24 & 7 & 10 \\
2 & SDN Katung & 29 & 75 & 69,31 & 13 & 16 \\
3 & SDN Sekaan & 25 & 75 & 72,40 & 10 & 15 \\
4 & SDN Bayung Gede & 29 & 78 & 72,76 & 9 & 20 \\
5 & SDN Bonyoh & 27 & 75 & 71,85 & 10 & 8 \\
6 & SDN Banua & 12 & 75 & 69,17 & 5 & 88 \\
\hline
\end{tabular}

(Sumber: Daftar Nilai UTS IPA Kelas V Semester I di Gugus III Kintamani)

Dilihat dari data yang terdapat pada Tabel 1 ternyata masih banyak nilai rata-rata UTS siswa kelas V di Gugus III Kintamani di bawah KKM yang ditemukan bahwa sebanyak 88 siswa nilainya belum mencapai KKM, dan hanya 54 siswa yang sudah mencapai KKM. Untuk mengatasi masalah di atas guru memegang peranan penting di dalam mengelola kelas dan menyampaikan pembelajaran khususnya pada pembelajaran IPA. Langkah yang dapat diambil guru adalah dengan menerapkan model pembelajaran yang tepat. Dalam penelitian ini model pembelajaran yang dapat diterapkan adalah model pemebelajaran Group Investigation (GI) berbasis Tri Hita Karana. 
Model pembelajaran group investigation (GI) adalah salah satu model pembelajaran yang mengembangkan kempauan investigasi dengan kerja sama kelompok. Model pembelajaran kooperatif tipe GI merupakan salah satu bentuk model pembelajaran kooperatif yang menekankan pada partisipasi dan aktivitas siswa untuk mencari sendiri materi (informasi) pelajaran yang akan dipelajari melalui bahan-bahan yang tersedia, misalnya dari buku pelajaran (Ariadi, Renda, \& Rati, 2014). Menurut Sai (2017) menyatakan Model pembelajaran GI merupakan salah satu bentuk pembelajaran yang menekankan pada aktivitas siswa untuk mencari sendiri tema (informasi) pelajaran yang akan dipelajari melalui bahan-bahan yang tersedia, misalnya dari buku pelajaran atau siswa dapat mencari melalui internet dan perpustakaan. Siswa dilibatkan sejak perencanaan, baik dalam menentukan tema maupun cara untuk mempelajarinya melalui investigasi. Supriyati \& Mawardi (dalam Wijaya, dkk., 2018) menyatakan model pembelajaran GI adalah model kegiatan pembelajaran yang bersifat dipimpin oleh wakil dari anggota kelompoknya yang diwujudkan dalam diskusi kelompok, yang berusaha untuk memecahkan suatu masalah terdiri dari kelompok kelompok kecil. Sedangkan menurut Wijaya, dkk. (2018) model pembelajaran GI merupakan model yang berbasis kelompok yang saling bekerjasama mempelajari pengetahuan yang bersifat akademis dalam mencari permasalahan. Sehingga dapat disimpulkan Model pembelajaran GI yang merupakan model pembelajaran yang memberikan kesempatan kepada siswa untuk menyesaikan persoalan yang telah ditentukan melalui invesitgasi atau siswa mencari materi pembelajaran yang terkait secara kelompok yang bisa bersumber dari buku, perpustakaan, internet, bahkan lingkungan yang berada di sekitar siswa, sehingga secara teori bisa memberikan pengaruh terhadap hasil belajar siswa. Sedangkan Artini, Pasaribu, \& Husain (2016) menyatakan bahwa model group investigation dipilih karena dapat memberikan kesempatan bagi siswa untuk berpartisipasi dalam memecahkan masalah yang dikaji antar individu dalam kelompoknya untuk memperoleh kesepakatan dalam penyelesaian permasalahan yang diberikan oleh guru. Dari jababaran tersebut dapat dikatakan dengan adanya model GI dapat mengembangkan kemampuan berkerjasamanya dan matematisnya karena model ini mengaktifkan siswa dalam memecahkan masalah dengan investigasi atau percobaan sederhana.

Model Group investigasi mempunyai kelebihan dibandingkan dengan model yang lain, Slavin (2015) menrumuskan beberapa kelebihan model GI yaitu: 1) Model ini sangat edial diterpakan untuk meningkatkan kemampuan kreativiats siswa. 2) Mampu mengembangkan kemapuan tingkat tinggi karena dalam proses pemecahan masalahnya menggunkan metode investigasi. 3) Mengembangkan kemampuan interaksi sosial anak karena anak akan bekerja bersama untuk memecahkan masalah dalam kelompok yang heterogen. 4) kegiatan berfokus pada peserta didik, sehingga anak mampu membangun pengetahuannya sendiri. 5) Meningkatkan pengembangan softskills kritis, komunikasi kreatif dan Group Process Skill (managemen kelompok). 6) anak akan mampu memcahkan masalah dnegan cepat karena model ini menggunakan segala sumber belajar yang ada. 7) Mengembangkan pemahaman peserta didik melalui berbagai kegiatan kelompok. 8) Mampu menumbuhkan sikap saling menghargai, saling memperkuat ikatan sosial, tumbuh sikap untuk lebih mengenal kemampuan diri sendiri, bertanggung jawab dan merasa berguna untuk orang lain. 9) Dapat mengembangkan kemampuan professional guru dalam mengembangkan pikiran kreatif dan inovatif.

Hal ini juga didukung oleh penelitian sebelumnya yang dilakukan oleh Wahyuningsih (2017) yang berjudul Pengaruh Model Pembelajaran Kooperatif Tipe Group Investigation terhadap Hasil Belajar IPA Siswa Kelas VII di SMP Taman Dewasa Jetis Yogyakarta Tahun Ajaran 2015/2016 menyimpulkan Model Pembelajaran Kooperatif Tipe Group Investigation memang memberikan pengaruh terhadap hasil belajar IPA siswa. Penelitian juga dilakukan oleh Dewi, Manuaba, \& Suniasih (2017) yang berjudul Pengaruh Model Pembelajaran Group Investigation Berbasis Proyek Terhadap Hasil Belajar IPA Siswa Kelas IV SD Gugus 1 Abiansemal Tahun Ajaran 2016/2017. Menyimpulkan model pembelajaran kooperatif tipe GI berbasis proyek berpengaruh terhadap hasil belajar IPA Siswa Kelas IV SD Gugus 1 Abiansemal tahun ajaran 2016/2017, hal ini terbukti dari perbedaan hasil belajar kelompok eksperimen dan kelompok kontrol. Serta penelitian yang dilakukan oleh Khasanah, Sekaringtyas, \& Soleh (2019) yang berjudul Pengaruh Penggunaan Model Pembelajaran Kooperatif Tipe Group Investigation (GI) Terhadap Kecerdasan Interpersonal Siswa dalam Pembelajaran Ilmu Pengetahuan Alam Kelas IV Sekolah Dasar. Menyimpulkan bahwa adanya pengaruh yang signifikan pada penggunaan model pembelajaran kooperatif tipe group investigation terhadap kecerdasan interpersonal siswa di kelurahan Pulogebang Jakarta Timur. Berdasarkan penelitian terdahulu yang telah dilakukan dapat disimpulkan bahwa model Group Investigation memberikan pengaruh yang signifikan terhadap hasil belajar IPA siswa.

Agar proses pembelajaran yang dilaksanakan berjalan dengan maksimal, maka perlu dipadukan dengan salah satu kearifan lokal yang ada di Bali yaitu Tri Hita Karana. Pradnyawathi \& Agustika (2019) menyatakan, Tri Hita Karana merupakan salah satu kearifan lokal yang mengemukakan tentang hubungan 
baik manusia dengan Tuhan, sesama manusia, dan lingkungan tempat tinggalnya yang memiliki konsep mengajarkan manusia untuk senantiasa menjaga keharmonisan di dunia mulai dari diri sendiri dan segala sesuatu yang ada di sekitarnya. Bagian-bagian Tri Hita Karana adalah (1) hubungan harmonis dengan Tuhan (Parahyangan), (2) hubungan harmonis dengan alam/lingkungan (Palemahan), dan (3) hubungan harmonis dengan manusi itu sendiri (Pawongan) (Santyasa, 2015). Sehingga dapat disimpulkan model pembelajaran Group Investigation (GI) berbasis Tri Hita Karana merupakan model pembelajaran yang mengajak siswa secara langsung mencari sumber balajar yang mendukung yang tetap menjaga hubungan harmonis sesuai dengan ajaran Tri Hita Karana. Hal ini juga di dukung oleh pendapat (Widiartini et al., 2019) yang menyatakan Model pembelajaran Group Investigation (GI) berbasis Tri Hita Karana merupakan model pembelajaran menggunakan sistem berkelompok saling bekerjasama menjalin hubungan harmonis dengan Tuhan, sesama manusia, dan dengan lingkungannya, sehingga semua anggota kelompok berhasil mencapai tujuan pembelajaran.

Model pembelajaran Group Investigation (GI) berbasis Tri Hita Karana terdiri dari 6 tahap atau langkah seperti pendapat Kurniasih \& Sani (2017) yang terdiri dari (1) Menyeleksi topik, Tahap pertama siswa memilik berbagai subtopik dalam materi yang akan dipelajari atau dari gambaran yang diberikan oleh guru. Kemudian megorganisir siswa menjadi kelompok-kelompok yang berorientasi pada tugas yang beranggotaan 2 sampai 6 orang. (2) Merencanakan kerjasama, Bersama-sama dengan siswa, guru merencanakan berbagai prosedur belajara, tugas dan tujuan umum yang konsisten dengan berbagai topik dan subtopik yang telah dipilih dari langkah 1 di atas. (3) Pelaksanaan, Para siswa melaksanakan rencana yang telah dirumuskan pada langkah (merencanakan kerjasama) di atas. Proses pelaksanaan melibatkan berbagai aktivitas dan keterampilan dengan variasi yang luas dan mendorong para siswa untuk menggunakan berbagai sumber baik yang terdapat di dalam maupun diluar sekolah. Guru harus memastikan setiap kelompok tidak mengalami kesulitan. (4) Analisis dan sistesis, Para siswa menganalisis dan mensintesis berbagai informasi yang diperoleh pada langkah (pelaksanaan) dan merencanakan agar dapat diringkaskan dalam suatu penyajian yang menarik di depan kelas. (5) Penyajian hasil akhir, Dengan pengawasan guru, setiap kelompok mempresentasikan berbagai topik yang telah dipelajari agar semua siswa dalam kelas saling terlibat dalam mencapai suatu perspektif luas mengenai topik tersebut. (6) Melakukan evaluasi, Bersama-sama siswa dan guru melakukan evaluasi mengenai kontribusi tiap kelompok terhadap pekerjaan kelas sebagai suatu keseluruhan.

Menggunakan model pembelajaran Group Investigation berbasis Tri Hita Karana tentu dapat mengarahkan siswa dalam proses pembelajaran yang lebih aktif dan terjadinya hubungan yang harmonis dalam setiap interaksi yang terjadi, sehingga diharapkan dapat berpengaruh terhadap hasil belajar IPA. Hal ini senada dengan penelitian yang telah dilakukan oleh (Widiartini et al., 2019). Menyatakan model pembelajaran Group Investigation (GI) Berbasis Tri Hita Karana berpengaruh terhadap hasil belajar IPA. sebab, berdasarkan hasil analisis statistik deskriptif kompetensi pengetahuan IPA kelompok eksperimen diperoleh $\bar{X}=75,72$. Dan kelompok kontrol diperoleh $\bar{X}=63$, 66. Sehingga disimpulkan bahwa dalam penelitian ini model group investigation berbasis Tri Hita Karana berpengaruh terhadap kompetensi pengetahuan IPA. Serta didukung juga dengan penelitian yang dilakukan oleh Indrayani, Japa, \& Arini (2019) menyatakan bahwa skor rata -rata hasil belajar kelompok eksperimen yang dibelajarkan menggunakan model pembelajaran siklus belajar berbasis tri hita karana lebih tinggi dibandingkan dengan skor rata -rata hasil belajar kelompok kontrol. Selain itu, terjadi perubahan sikap pada siswa yang dibelajarkan dengan menggunkan model pembelajaran berbasis tri hita karana yaitu pada unsur parhyangan siswa menjadi terbiasa dan khusuk berdoa sebelum dan setelah proses pembelajaran. Sehingga model pembelajaran siklus belajar berbasis tri hita karana berpengaruh terhadap hasil belajar IPA siswa.

Berdasarkan uraian di atas, penggunaan model pembelajaran Goup Investigation (GI) berbasis Tri Hita Karana secara teoritis memiliki pengaruh terhadap hasil belajar IPA siswa. Selanjutnya, untuk mengukur besarnya pengaruh secara empiris, maka dilakukan sebuh penelitian yang berjudul "Pengaruh Model Pembelajaran Goup Investigation (GI) Berbasis Tri Hita Karana Terhadap Hasil Belajar IPA siswa".

Adapun tujuan yang ingin dicapai dalam penelitian ini yaitu untuk mengetahui pengaruh yang signifikan model pembelajaran Group Investigation berbasis Tri Hita Karana terhadap hasil belajar IPA siswa kelas V SD Gugus III Kecamatan Kintamani Tahun Pelajaran 2019/2020.

\section{Metode}

Tempat penelitian ini adalah di Gugus III Kecamatan Kintamani, Kabupaten Bangli pada siswa kelas V SD pada tahun pelajaran 2019/2020 yang berlangsung dari tanggal 15 Januari 2020 sampai 10 Pebruari 2020. Jenis penelitian ini adalah Penelitian eksperimen semu (Quasi eksperimen) dengan desain penelitian yang digunakan adalah Nonequivalent post test only control group desain. Maksud dari Nonequivalent post 
test only control group desain yaitu random hanya diberlakukan untuk menentukan kelompok eksperimen dan kelompok kontrol dari populasi dan hanya menggunakan post test pada kelompok eksperimen dan kelompok kontrol pada akhir penelitian. Hasil post test kedua kelompok akan dibandingkan untuk menentukan berpengaruh tidaknya perlakuan yang diberikan terhadap hasil belajar IPA pada ranah kognitif.

Populasi dari penelitian ini adalah seluruh siswa kelas V SD Gugus III Kecamatan Kintamani tahun pelajaran 2019/2020, yang terdiri 139 siswa dari 6 Sekolah yang ada di Gugus III. Setelah mengetahui populasi langkah selanjutnya yaitu menentukan sampel penelitian. Pengambilan sampel pada penelitian ini menggunakan teknik pengampilan sampel dari populasi secara sederhana dengan cara undian (simple random samping). Sampel pada penelitian ini adalah kelas, dengan alasan karena tidak memungkinkan untuk mengubah kelas yang sudah ada. Kelas yang digunakan merupakan kelas pada jenjang yang sama yaitu kelas V SD yang berada di Gugus III Kecamatan Kintamani yang telah melalui Uji kesetaraan dengan menggunakan analisis varian satu jalur (Anava A) dengan cara manual dan bantuan Microsoft Excel 2013 for Windows.

Data yang dikumpulkan pada penelitian ini adalah hasil belajar IPA siswa kels V SD Gugus III Kecamatan Kintamani Tahun pelajaran 2019/2020. Pengumpulan data hasil belajar IPA pada ranah kognitif dalam penelitian ini menggunakan metode tes. Tes berupa pilihan ganda yang akan diberikan pada akhir penelitian (post test). Tes yang digunakan adalah tes pilihan ganda dengan satu jawaban benar. Tes tersebut disusun berdasarkan kisi-kisi soal yang telah dibuat sesuai dengan KD dan indikator. Setelah kisi-kisi dibuat, sebelum digunakan untuk mengukur hasil belajar IPA, terlebih dahulu sebuah kisi-kisi yang berupa istrumen akan diuji. Uji intrumen berupa uji validitas, uji, reliabilitas, daya beda dan tingkat kesaukaran.

Analisis hasil penelitian yang digunakan dalam penelitian ini adalah analisis deskriptif dan analisis inferensial. Analisis deskriptif digunakan untuk mendeskripsikan hasil belajar IPA siswa yang dibelajarkan menggunakan model pembelajarn Group Investigation (GI) berbasis Tri Hita Karana dan hasil belajar IPA siswa yang dibelajarkan dengan pembelajaran konvensional. Adapun yang dihitung menggunakan Statistik Deskripsi yaitu: a) Menghitung Mean, b) Menghitung Median, c) Menghitung Modus, d) Menghitung Standar Deviasi, dan e) Menghitung Varians. Setelah selesai mengolah data menggunakan statistik deskriptif maka dilanjutkan dengan analisis inferensial. Analisis statistik inferensial ialah suatu cara pengolahan data yang menggunakan rumus-rumus statistik inferensial untuk menguji hipotesis penelitian, dan untuk penarikan kesimpulan. Adapun analisis statistik inferensial yang digunakan untuk uji prasyaratan yaitu uji normalitas data dan uji homogen varian.

Uji normalitas data dilakukan untuk menyajikan bahwa sampel benar-benar berasal dari populasi yang berdistribusi normal. Uji normalitas data penelitian ini menggunakan uji Chi-Square $\left({ }^{x_{2}}\right)$ pada taraf signifikan $5 \%$ dan derajat kebebasan $\mathrm{dk}=$ jumlah kelas $-2-1$. Kriteria pengujian data berdistribusi normal jika $\chi_{2}$ hitung $<\chi_{2}$ tabel. Sedangkan uji homogenitas Varians bertujuan untuk mengetahui bahwa kedua kelompok mempunyai varian yang sama atau tidak. Perhitungan uji homogen varian dilakukan menggunakan uji $\mathrm{F}$ dengan kriteria pengujian jika $\mathrm{F}_{\text {hitung }}<\mathrm{F}$ tabel maka sampel homogen. sebaliknya, jika $\mathrm{F}$ hitung $>\mathrm{F}$ tabel maka sampel tidak homogen. Pengujian dilakukan pada taraf signifikansi 5\%.

Uji hipotesis yang digunakan dalam penelitian ini menggunakan uji-t. hal ini dikarenakan Penelitian ini menggunakan satu variabel bebas dan satu variabel terikat, sehingga uji hipotesis yang akan dilakukan menggunakan analisis Uji-t. Karena seperti fungsi dari Uji-t yaitu untuk menguji perbedaan nilai rata-rata hitung antara dua kelompok sampel.

\section{Hasil dan pembahasan}

Penelitian ini bertujuan untuk mengetahui pengaruh yang signifikan model pembelajaran Group Investigation berbasis Tri Hita Karana terhadap hasil belajar IPA siswa kelas V SD. Penelitian ini dilakukan di SD Gugus III Kecamatan Kintamani sebagai populasi dengan menggunakan 2 sampel penelitian yaitu, SDN Bayung Gede sebagai kelompok Eksperimen dan SDN Sekaan sebagai kelompok Kontrol. Data yang dikumpulkan dan yang dianalisis adalah data hasil belajar IPA siswa kelas V SD Gugus III Kecamatan Kintamani pada ranah kognitif yang berbentuk skor. Data yang diperoleh dalam penelitian ini diperoleh dari posttes yang telah diberikan. Instrument yang digunakan untuk posttes sudah memenuhi persyaratan sebuah istrumen dengan melakukan uji pakar/ahli, uji validitas, rasbilitas, tingkat kesukaran, daya beda, dan uji coba instrument. Posttes yang telah dilakukan diberikan soal pilihan ganda sebanyak 25 butir soal yang merupakan perwakilan dari masing-masingg indikator dalam pembelajaran. Sebelum melaksanakan posttes kenapa sampel penelitian dilakuka pertemuan proses pembelajaran sebanyak 9 kali dalam satu tema. Pertemuan yang dilakukan yaitu dengan memberikan perlakuan kepada kelompok eksperimen 
dengan melaksanakan proses pembelajaran menggunakan model pembelajaran Group Investigation (GI) berbasis Tri Hita karana dan tanpa memberikan perlakuan khusus pada kelompok kontrol atau hanya melaksanakan proses pembelajran menggunakan model pembelajaran Konvensional. Banyaknya siswa yang dianalisis dalam penelitian ini yaitu 29 siswa di kelompok ekserimen dan 25 siswa di kelompok kontrol. Adapun hasil posttest yang telah didapatkan pada sampel dilakukan analisis deskriptif dan disajikan dalam tabel 02 berikut.

Tabel 02. Rekapitulasi Hasil Penghitungan Statistik Deskriptif Post-test Skor Hasil Belajar IPA Kelompok Eksperimen dan Kelompok Kontrol

\begin{tabular}{ccc}
\hline Statistik Deskriptif & \multicolumn{2}{c}{ Hasil Belaja Post-test } \\
& Kelompok Eksperimen & Kelompok Kontrol \\
\hline Mean & 19,62 & 15.16 \\
Median & 19 & 15 \\
Modus & 19 & 15 \\
Stadar deviasi & 2.19 & 3.68 \\
Varian & 4.81 & 13.56 \\
Minimum & 16 & 9 \\
Maximum & 23 & 21 \\
$\mathrm{n}$ & 29 & 25 \\
\hline
\end{tabular}

Tabel 02 menunjukkan hasil perhitungan statistik deskriptif posttest skor hasil belajar IPA siswa diperoleh rata-rata hasil belajar kelompok eksperimen 19.62. Sedangkan rata-rata hasil belajar kelompok kontrol 15.16. Median yang diperoleh dari kelas eksperimen $=19$, sedangkan dari kelas kontrol $=15$. Modus dari kelas eksperimen = 19 dan kelas kontrol = 15. Dari data tersebut menujukkan bahwa hasil belajar IPA kelompok eksperimen lebih tinggi dari kelompok kontrol. Sedangkan dilihat dari pemerolehan skor, skor tertinggi di kelompok eksperimen adalah 23 dari 25 soal yang diberikan, dan pada kelompok kontrol skor tertingginya adalah 21 dari 25 soal. Sehingga untuk kecendrungan klasifikasi hasil belajar IPA siswa kelas V SD Negeri Bayunggede dan siswa kelas V SD Negeri Sekaan digunakan suatu kriteria dengan skala lima yang telah disusun. Kriteria dengan skala lima hasil belajar kelompok eksperimen termasuk kedalam kriteria sangat tinggi yaitu dengan rata rata skor hasil belajar IPA 19,62, sehingga berada pada rentangan $18,8 \leq \bar{X} \geq 25,1$. Sedangkan pada kelompok kontrol termasuk kedalam kriteria baik yaitu dengan rata-rata 15,16 , sehingga berada pada rentangan $14,6 \leq \bar{X} \geq 18,8$.

Sebelum dilakukan uji hipotesis dengan uji-t, terlebih dahulu harus melakukan pengujian asumsi yang meliputi uji normalitas data dan uji homogen varian. Uji normalitas dilakukan untuk mengetahui data yang diperoleh berdistribusi normal atau tidak. Uji normaltas dalam penelitian ini menggunakan uji Chi-Square $\left(x^{2}\right)$ dengan tarap signifikan 5\% dan derajat kebebasan dk= jumlah kelas $-2-1$ dengan kriteria $x^{2}$ hitung $<x^{2}$ tabel. Pada tabel 04 di bawah dijabarkan perolehan rekapitulasi normalitas data.

Tabel 04. Rekapitulasi Uji Normalitas Data

\begin{tabular}{ccccc}
\hline No & Sampel & ${ }^{\chi_{2}}$ hitung & ${ }^{\chi_{2}}$ tabel & Keterangan \\
\hline 1 & Kelompok Eksperimen & 3.26 & 12,592 & Normal \\
2 & Kelompok Kontrol & 14.68 & 18,307 & Normal \\
\hline
\end{tabular}

Tabel 4 menunjukkan nilai $x^{2}$ hitung $<x^{2}$ tabel baik itu di kelompok eksperimen maupun dikelompok kontrol. Sehingga hal ini menunjukkan bahwa sampel dalam penelitian ini berdistribusi normal. Sedangkan untuk uji homogen varian dilakukan untuk mengetahui sampel dalam penelitian mempunyai varia atau tidak. Uji homogen varian dilakukan menggunakan uji $\mathrm{F}$ dengan kriteria $\mathrm{F}_{\text {hitung }}<\mathrm{F}_{\text {tabel }}$ dinyatakan homogen, dan tidak homogen apabila $F_{\text {hitung }}>F_{\text {tabel }}$ pada taraf siggnifikan 5\%. Adapun rekapitulasi uji homogen dijabarkan dalam tabel 05 berikut.

Tabel 05. Rekapitulasi Uji Homogen Varian

\begin{tabular}{ccccc}
\hline No & Sampel & $F_{\text {hitung }}$ & $F_{\text {tabel }}$ & Keterangan \\
\hline 1 & Eksperimen & 2,81 & 4,03 & Homogen \\
2 & Kontrol & & & \\
\hline
\end{tabular}


Berdasarkan tabel 5 dapat diketahui skor hasil belajar IPA kedua sampel dalam penelitian ini $F_{\text {hitung }}$ $<\mathrm{F}_{\text {tabel. }}$ Sehingga sampel penelitian ini adalah homogen.

Pengujian hipotesis dilakukan setelah dilakukan uji normalitas dan uji homogenitas, diperoleh bahwa data hasil belajar IPA kelompok eksperimen dan kelompok kontrol adalah normal dan homogen.. Pengujian hipotesis dilakukan dengan menggunakan Uji-t dengan rumus polled varians. Kriteria pengujian yaitu jika thitung $\geq$ ttabel $\mathrm{HO}$ ditolak. Rangkuman analsis uji hipotesis dijabarkan pada tabel 06 berikut.

Tabel 06. Hasil Uji Hipotesis

\begin{tabular}{ccccccc}
\hline Kelompok Data Hasil Belajar IPA & Varian & $\mathrm{N}$ & $\mathrm{Dk}$ & thitung & tabel & kesimpulan \\
\hline $\begin{array}{c}\text { Eksperimen } \\
\text { Kontrol }\end{array}$ & 4,82 & 29 & 52 & 5,71 & 2,021 & $\begin{array}{c}\text { thitung }>\text { tabel } \\
\text { H0 ditolak }\end{array}$ \\
\hline
\end{tabular}

Berdasarkan Tabel 6 diketahui bahwa thitung sebesar 5,71 dan tabel sebesar 2,021 pada taraf signifikan 5\% dengan derajat kebebasan (n1-n2)-2. Hal ini berarti thitung lebih besar dari ttabel (thitung $>t_{\text {tabel }}$ ) sehingga $\mathrm{HO}$ ditolak dan $\mathrm{H} 1$ diterima. Dengan demikian dapat disimpulkan bahwa terdapat pengaruh yang signifikan model pembelajaran Group Investigation (GI) berbasis Tri Hita Karana terhadap hasil belajar IPA siswa kelas V SD Gugus III Kecamatan Kintamani Tahun Pelajaran 2019/2020.

Pertama, model koperatif tipe GI adalah salahs atu model pembelajaran yang mengkolaborasi antara bekerja sama dengan proses investigasi. Dalam proses pembelajaran yang dilakukan GI sangat menekankan terhadap proses kerjasama kelompok yang heterogen yang berasal suku yang berbeda, budaya yang berbeda serta kemapuan kognitif yang berbeda, dengan perbedaaan pengetahuan yang berbeda ini anak-anak akansaling menambahkan dan melengkapi sampai tujuan pembelajaran tercapai. buku pelajaran (Ariadi et al., 2014). Menurut Sai (2017) menyatakan Model pembelajaran GI merupakan salah satu bentuk pembelajaran yang menekankan pada aktivitas siswa untuk mencari sendiri tema (informasi) pelajaran yang akan dipelajari melalui bahan-bahan yang tersedia, misalnya dari buku pelajaran atau siswa dapat mencari melalui internet dan perpustakaan. Siswa dilibatkan sejak perencanaan, baik dalam menentukan tema maupun cara untuk mempelajarinya melalui investigasi. Supriyati \& Mawardi (dalam Wijaya, dkk., 2018) menyatakan model pembelajaran GI adalah model kegiatan pembelajaran yang bersifat dipimpin oleh wakil dari anggota kelompoknya yang diwujudkan dalam diskusi kelompok, yang berusaha untuk memecahkan suatu masalah terdiri dari kelompok kelompok kecil. Sedangkan menurut Wijaya, dkk. (2018) model pembelajaran GI merupakan model yang berbasis kelompok yang saling bekerjasama mempelajari pengetahuan yang bersifat akademis dalam mencari permasalahan. Sehingga dapat disimpulkan Model pembelajaran GI yang merupakan model pembelajaran yang memberikan kesempatan kepada siswa untuk menyesaikan persoalan yang telah ditentukan melalui invesitgasi atau siswa mencari materi pembelajaran yang terkait secara kelompok yang bisa bersumber dari buku, perpustakaan, internet, bahkan lingkungan yang berada di sekitar siswa, sehingga secara teori bisa memberikan pengaruh terhadap hasil belajar siswa. Sedangkan Artini et al., (2016) menyatakan bahwa model group investigation dipilih karena dapat memberikan kesempatan bagi siswa untuk berpartisipasi dalam memecahkan masalah yang dikaji antar individu dalam kelompoknya untuk memperoleh kesepakatan dalam penyelesaian permasalahan yang diberikan oleh guru. Dari jababaran tersebut dapat dikatakan dengan adanya model GI akan dapat mengembangkan kemampuan berkerjasamanya dan matematisnya karena model ini mengaktifkan siswa dalam memecahkan masalah dengan investigasi atau percobaan sederhana.

Model Group investigasi mempunyai kelebihan dibandingkan dengan model yang lain, Slavin (2015) menrumuskan beberapa kelebihan model GI yaitu: 1) model ini sangat edial diterpakan untuk meningkatkan kemampuan kreativiats siswa. 2) Mampu mengembangkan kemapuan tingkat tinggi karena dalam proses pemecahan masalahnya menggunkan metode investigasi. 3) mengembangkan kemampuan interaksi sosial anak karena anak akan bekerja bersama untuk memecahkan masalah dalam kelompok yang heterogen. 4) kegiatan berfokus pada peserta didik, sehingga anak mampu membangun pengetahuannya sendiri. 5) Meningkatkan pengembangan softskills kritis, komunikasi kreatif dan Group Process Skill (managemen kelompok). 6) anak akan mampu memcahkan masalah dnegan cepat karena model ini menggunakan segala sumber belajar yang ada. 7) Mengembangkan pemahaman peserta didik melalui berbagai kegiatan kelompok. 8) Mampu menumbuhkan sikap saling menghargai, saling memperkuat ikatan sosial, tumbuh sikap untuk lebih mengenal kemampuan diri sendiri, bertanggung 
jawab dan merasa berguna untuk orang lain. 9) Dapat mengembangkan kemampuan professional guru dalam mengembangkan pikiran kreatif dan inovatif.

Hal ini juga didukung oleh penelitian sebelumnya yang dilakukan oleh Wahyuningsih (2017) yang berjudul Pengaruh Model Pembelajaran Kooperatif Tipe Group Investigation terhadap Hasil Belajar IPA Siswa Kelas VII di SMP Taman Dewasa Jetis Yogyakarta Tahun Ajaran 2015/2016 menyimpulkan Model Pembelajaran Kooperatif Tipe Group Investigation memang memberikan pengaruh terhadap hasil belajar IPA siswa. Penelitian juga dilakukan oleh (Dewi et al., 2017) yang berjudul Pengaruh Model Pembelajaran Group Investigation Berbasis Proyek Terhadap Hasil Belajar IPA Siswa Kelas IV SD Gugus 1 Abiansemal Tahun Ajaran 2016/2017. Menyimpulkan model pembelajaran kooperatif tipe GI berbasis proyek berpengaruh terhadap hasil belajar IPA Siswa Kelas IV SD Gugus 1 Abiansemal tahun ajaran 2016/2017, hal ini terbukti dari perbedaan hasil belajar kelompok eksperimen dan kelompok kontrol. Serta penelitian yang dilakukan oleh (Khasanah et al., 2019) yang berjudul Pengaruh Penggunaan Model Pembelajaran Kooperatif Tipe Group Investigation (GI) Terhadap Kecerdasan Interpersonal Siswa dalam Pembelajaran Ilmu Pengetahuan Alam Kelas IV Sekolah Dasar. Menyimpulkan bahwa adanya pengaruh yang signifikan pada penggunaan model pembelajaran kooperatif tipe group investigation terhadap kecerdasan interpersonal siswa di kelurahan Pulogebang Jakarta Timur. Berdasarkan penelitian terdahulu yang telah dilakukan dapat disimpulkan bahwa model Group Investigation memberikan pengaruh yang signifikan terhadap hasil belajar IPA siswa

Kedua, Tri hita karana adalah sebuah trilogy yang sudah dikenal olehmasyarakat terutama masyrakat bali. Tri Hita Karana merupakan konsep budaya Bali, yaitu berasal dari ajaran agama Hindu, dan mengajarkan cara mengatur hubungan yang harmonis antara manusia dengan Tuhan, manusia dan lingkungannya (Artana, 2014). Pradnyawathi \& Agustika (2019) menyatakan, Tri Hita Karana merupakan salah satu kearifan lokal yang mengemukakan tentang hubungan baik manusia dengan Tuhan, sesama manusia, dan lingkungan tempat tinggalnya yang memiliki konsep mengajarkan manusia untuk senantiasa menjaga keharmonisan di dunia mulai dari diri sendiri dan segala sesuatu yang ada di sekitarnya. Bagian-bagian Tri Hita Karana adalah (1) hubungan harmonis dengan Tuhan (Parahyangan), (2) hubungan harmonis dengan alam/lingkungan (Palemahan), dan (3) hubungan harmonis dengan manusi itu sendiri (Pawongan) (Santyasa, 2015). Dengan adanya konsep Tri HIta Karana dalam proses pembelajaran akan membantu siswa untuk mengembangkan interaksi baik dengan tuhan konsep prahyangannya, dengan guru dan siswa lain konsep Pawonganya dan interaksi antara siswa denga sumber belajar, sumber belajar disini bisa lingkungan, buku media atau yang lainya konsep ini adalah konsep palemahan. Selain itu dengan diterpakan konsep Tri HIta Karana siswa akan dirangsang untung mengajukan pendapat, menghargai pendapat orang lain, serta mengahargai perbedan dan lebih peduli dengan lingkungan yang ada disekitarnya. Pernytaan ini sesaui dengan pendapat yang di nyatakan oleh Putra, Parmiti, \& Suwatra (2016) yaitu Tri Hita Karana akan mendorong siswa untuk belajar bermakna melalui interaksi-interaksi yang terjadi saat pembelajaran IPA berlangsung. Bagian Tri Hita Karana yang pertama Parhyangan, dengan penerapan bagian Tri Hita Karana ini siswa akan terbiasa untuk berdoa sebelum dan sesudah pembelajaran berlangsung. Kemudian, dengan menerapkan bagian Tri Hita Karana yang kedua yaitu Pawongan siswa akan terbiasa untuk saling menghargai pendapat dan perbedaan dengan temannya, sehingga suasana kelas menjadi harmonis. Kemudian yang ketiga Palemahan, dengan penerapan bagian Tr Hita Karana yang terakhir ini siswa akan terbiasa untuk memanfaatkan lingkungannya dengan bijak dan menjaga lingkungannya supaya tetap asri dan lestari.

Ketiga, berdasarkan hasil penelitian terdapat pengeruh adalah pengaruh yang positif. Terjadinya pengaruh disebabkan karena model pembelajaran Group Investigation (GI) berbasis Tri Hita Karana akan memberikan kesempata bagi siswa untuk berperan aktif dalam mencari informasi sesuai dengan hal yang akan dibahas dalam pembelajaran. Seperti pendapat Ariadi et al. (2014) Model pembelajaran group investigation merupakan model pembelajaran kooperatif yang menekankan pada partisipasi dan aktivitas siswa dalam bentuk kelompok yang heterogen untuk mencari sendiri materi (informasi) pelajaran yang akan dipelajari. Proses pencarian informasi yang akan dipelajari siswa tentu disertai dengan adanya interaksi atau hubungan. Interaksi yang dimaksud adalah interaksi yang harmonis dengan lingkungan sekitar, antar sesama, dan juga tentu dengan tuhan. Hubungan yang harmonis dengan alam, sesama, dan Tuhan juga diajarkan pada salah satu kearifan lokal masyarakat bali yaitu Tri Hita Karana. Tri Hita Karana merupakan tiga penyebab kebahagiaan yang terdiri dari hubungan harmonis dengan Tuhan (Pahyangan), hubungan harmonis dengan sesame (pawongan), dan hubungan harmonis dengan alam (palemahan). Sehingga adanya model pembelajaran GI berbasis Tri Hita Karana akan memberikan kesempatan bagi siswa dalam berbagai proses interaksi dalam mencari informasi yang berkaitan dengan pembelajaran yang tetap menekankan hubungan harmonis pada saat proses interaksi. baik itu dengan Tuhan (Prahyangan), dan alam/tingkungan (Palemahan), antar sesama (Pawongan). Sehingga didapatkan temuan penelitian hasil belajar yang berbeda pada kelompok eksperimen dan kontrol. Perbedaan hasil 
belajar yang ditemukan juga didukung oleh pendapat Widiartini et al. (2019) yang menyatakan kelebihan model pembelajaran Group Investigation (GI) berbasis Tri Hita Karana yaitu: (1) akan membuat siswa saling bekerjasama memecahkan masalah melalui hubungan keseimbangan yang harmonis dengan Tuhan, sesama manusia dan dengan lingkungan alam dan membuat siswa merasa bersemangat dan senang mengikuti pembelajaran. (2) penerapan nilai-nilai Tri Hita Karana dapat mempermudahkan siswa dalam memahami suatu konsep yang ada di mata pelajaran IPA. (3) Interaksi siswa dapat meningkat karena pada model ini siswa diberikan kesempatan untuk berdiskusi dan berinteraksi dengan temannya dalam menemukan dan memahami suatu konsep. (4) Setiap anggota kelompok bertanggung jawab atas segala sesuatu yang dikerjakan dalam kelompoknya dan membuat setiap siswa tidak ada yang diam. Serta Shoimin (2014) juga mengungkapkan kelebihan Group Investigation(GI) berbasis Tri dibagi menjadi tiga bagian yaitu (1) Secara pribadi, maksud dari secara pribadi adalah proses belajar siswa dapat bekerja secara bebas, rasa percaya diri siswa dapat meningkat, dan mengembangkan antusiasme, (2) Secara sosial, maksud secara sosial yaitu meningkatkan kerja sama, berkomunikasi dengan teman dan guru, belajar sikap menghargai pendapat orang lain, meningkatkan partisipasi dalam membuat suatu keputusan, dan (3) Secara akademis, maksud dari secara akademis yaitu siswa terlatih untuk mempertanggung jawabkan jawaban yang diberikan, merencanakan dan mengorganisasikan pekerjaannya, siswa dapat mengecek kebenaran jawaban yang mereka buat, siswa selalu berpikir tentang cara yang digunakan sehingga didapat suatu kesimpulan.

Penelitian ini juga diperkuat oleh penelitian yang dilakukan oleh Widiartini et al. (2019) yang berjudul pengaruh model pembelajaran Group Investigation berbasis Tri Hita Karana terhadap kompetensi pengetahuan IPA siswa kelasIV SD Gugus Pattimura Denpasar Selatan, menyatakan rata-rata kompetensi pengetahuan IPA siswa kelompok eksperimen lebih dari rata-rata kompetensi pengetahuan IPA siswa kelompok kontrol dan menyimpulkan bahwa model pembelajaran Group Investigation (GI) berbasis Tri Hita Karana berpengaruh terhadap kompetensi pengetahuan IPA siswa kelas IV SD Gugus Pattimura Denpasar Selatan. Penelitian yang dilakukan oleh Wibisana, Kusmariatni, \& Yudiana (2019) juga menyatakan rata-rata kompetensi pengetahuan IPS kelompok siswa yang mengikuti Model Pembelajaran Cooperatif Script berbasis Tri Hita Karana lebih besar daripada rata-rata kompetensi pengetahuan IPS kelompok siswa yang menggunakan model pembelajaran konvensional dan menyimpulkan terdapat perbedaan yang signifikan kompetensi pengetahuan IPS antara kelompok siswa yang dibelajarkan menggunakan model pembelajaran Cooperatif Script dengan kelompok siswa yang dibelajarkan menggunakan model konvensional. Serta penelitian yang dilakukan oleh Indriani (2019) menyatakan bahwa skor rata -rata hasil belajar kelompok eksperimen yang dibelajarkan menggunakan model pembelajaran siklus belajar berbasis tri hita karana lebih tinggi dibandingkan dengan skor rata rata hasil belajar kelompok kontrol dan menyimpulkan model pembelajaran siklus belajar berbasis tri hita karana berpengaruh terhadap hasil belajar IPA siswa.

Berdasarkan hasil penelitian serta penelitian pendukung dapat dikatan bahwa terdapat pengeruh model pembelajaran Group Investigation (GI) Berbasis Tri Hita Karana terhadap hasil belajar IPA siswa. Hal ini tidak terlepas dari kelbihan dari model GI sendiri serta kelebihan dari Konsep Tri Hita Karana. Kombinasi model ini berpengeruh terhadap suasana pembelajaran didalam kelas serta langkahlangkahnya membeantu siswa lebih aktif adaam proses pembelajaran serta menumbuhkan kemapuan interaksi sosial antar komponen pembelajaran yang secara tidak langsung akan mem[engaruhi penguasaan akan materi sehingga tujuan dari pembelajaran itu dapat dicapai.

\section{Simpulan dan saran}

Setelah dilakukan analisis data dan berdasarkan hasil perhitungan uji-t, diperoleh thitung sebesar 5,71 dan tabel pada taraf signifikan $5 \%$ dan $\mathrm{dk}=(29+25)-2=52$ adalah 2,021. Hal ini berarti thitung $\geq$ tabel maka perhitungan tersebut membuktikan bahwa hipotesis alternatif $\left(\mathrm{H}_{1}\right)$ diterima dan $\mathrm{H}_{0}$. Ini berarti bahwa terdapat pengaruh yang signifikan model pembelajaran kooperatif Group Investigation (GI) berbasis Tri Hita Karana terhadap hasil belajar IPA siswa kelas V SD Gugus III Kecamatan Kintamani Tahun Pelajaran 2019/2020.

Berdasarkan uraian dan simpulan di atas, ada beberapa saran yang dapat disampaikan kepada beberapa pihak diantaranya, (1) Kepala sekolah dapat menggunakan penelitian ini sebagai rujukan dalam upaya menambah pengetahuan dan wawasan untuk meningkatkan kualitas pembelajaran dan untuk mengoptimalkan hasil belajar IPA siswa sehingga kualitas pembelajaran siswa menjadi optimal. (2) Guru di sekolah dasar agar lebih berinovasi dalam melaksanakan pembelajaran dengan menerapkan model pembelajaran yang bervariari sehingga hasil belajar siswa juga akan lebih baik. (3) Peneliti lain yang ingin mengadakan penelitian lebih lanjut tentang model pembelajaran Group Investigation (GI) berbasis 
Tri Hita Karana dalam mata pelajaran IPA maupun bidang ilmu lain yang sesuai agar memerhatikan kekurangan-kekurangan yang ditemukan dalam penelitian ini, sehingga hasil penelitian ini dapat dijadikan sebagai bahan pertimbangan untuk melaksanakan penelitian selanjutnya.

\section{Daftar Rujukan}

Abdullah. (2017). Pendekatan dan Model Pembelajaran yang Mengaktifkan Siswa. Edureligia, 1(1), 45-62.

Ariadi, I. P., Renda, N. T., \& Rati, N. W. (2014). Pengaruh Model Pembelajaran Group Investigation ( GI ) Terhadap Hasil Belajar IPA kelas IV. E-Journal Mimbar PGSD Universitas Pendidikan Ganesha, 2(1).

Artana, I. W. (2014). Tri Hita Karana Meningkatkan Kualitas Modal Manusia dari Persepektif Kesehatan. Jurnal Kependudukan dan Pengembangan Sumber Daya Manusia, X(2), 100-105.

Artini, Pasaribu, M., \& Husain, S. N. (2016). Penerapan Model Pembelajaran Kooperatif Tipe Goup Investigation Untuk Meningkatkan Aktivitas dan Hasil Belajar IPA Pada Siswa Kelas VI SD Inpres 1 Tondo. E-Jurnal Mitra Sains, 4(1), 76-83.

Dewi, P. P. Y., Manuaba, I. S., \& Suniasih, N. W. (2017). Pengaruh Model Pembelajaran Group Investigation Berbasis Proyek Terhadap Hasil Belajar IPA Siswa Kelas IV. International Journal of Elementary Education, 1(4), 264-271.

Indrayani, S. A. P., Japa, I. G. N., \& Arini, N. W. (2019). Pengaruh Model Pembelajaran Siklus Belajar Berbasis Tri Hita Karana Terhadap Hasil Belajar IPA Siswa Kelas V di Gugus IV Kecamatan Banjar. Jurnal Pendidikan Multikultural Indonesia, 2(2), 76-86.

Indriani. (2019). Hasil PISA Tunjukkan Perspektif Pendidikan Indonesia. Antara News.

Jayani, D. H. (2019). Kemampuan Siswa Indonesia di Bawah Rata-rata OECD. Retrieved from https://katadata.co.id/infografik/2019/12/16/kemampuan-siswa-indonesia-di-bawah-rata-rataoecd

Khasanah, N., Sekaringtyas, T., \& Soleh, D. A. (2019). Pengaruh Penggunaan Model Pembelajaran Kooperatif Tipe Group Investigation (GI) terhadap Kecerdasan Interpersonal Siswa dalam pembelajaran Ilmu Pengetahuan Alam Kelas IV Sekolah Dasar. Dinamika IPA Sekolah Dasar, 1(1), 113.

Kristinawati, D., Akbar, S., \& Mahanal, S. (2017). Implementasi Model Brain Based Learning dengan Mind Map Pada Pembelajaran IPA Kelas V Sekolah Dasar. Prosiding TEP \& PDs Transformasi Pendidikan Abad 21, 6(11), 637-644.

Kurniasih, \& Sani. (2017). Pagam Pengembangan Model Pembelajaran Untuk Meningkatkan Profsionalitas Guru. Jakarta: Kata Pena.

Lestari, H., Ayub, S., \& Hikmawati. (2016). Penerapan Model Pembelajaran Sains Teknologi Masyarakat ( STM ) untuk Meningkatkan Hasil Belajar Fisika Siswa Kelas VIII SMPN 3 Mataram. Jurnal Pendidikan Fisika Dan Teknologi, II(3), 111-115.

Pradnyawathi, N. N. C., \& Agustika, G. N. S. (2019). Pengaruh Model Pakem Berbasis Tri Hita Karana terhadap Keterampilan Menulis. International Journal of Elementary Education, 3(1), 89-98.

Putra, I. W. W. G., Parmiti, D. P., \& Suwatra, I. I. W. (2016). Pengaruh Model Pembelajaran SAVI Bermuatan Tri Hita Karana Terhadap Hasil Belajar Ipa Siswa Kelas IV. E-Journal PGSD Universitas Pendidikan Ganesha, 4(1), 1-9.

Sai, M. (2017). Pengaruh Model Pembelajaran Group Investigation Berbasis Internet Terhadap Hasil Belajar dan Kemampuan Digital Literasi Siswa pada Pembelajaran IPS. Jurnal Penelitian Pendidikan, 34(1), 37-54.

Santyasa, I. W. (2015). Pendidikan Agama Hindu. Singaraja.

Shoimin, A. (2014). 68 Model Pembelajaran Inovatif dalam Kurikulum 2013. Yogyakarta: AR-Ruzz Media.

Wahyuningsih, I. (2017). Pengaruh Model Pembelajaran Kooperatif Tipe Group Investigation Terhadap Hasil Belajar IPA. Jurnal Ilmiah Pendidikan IPA, 4(1), 26-33.

Wibisana, I. K., Kusmariatni, N. N., \& Yudiana, K. (2019). Pengaruh Model Cooperatif Script Berbasis Tri Hita Karana Terhadap Kompetensi Pengetahuan IPS Siswa Kelas IV. Jurnal Pendidikan Multikultural 
Indonesia, 2(2), 66-75.

Widiartini, P. D. O., Putra, M., \& Manuaba, I. B. S. (2019). Pengaruh Model Pembelajaran Group Investigation Berbasis Tri Hita Karana Terhadap Kompetensi Pengetahuan IPA. Jurnal Ilmiah Sekolah Dasar, 3(3), 332-340.

Wijaya, \& dkk. (2018). Upaya Peningkatan Hasil Belajar Menggunakan Group Investigation Pada Siswa Kelas 4 Sekolah Dasar. Jurnal Pendidikan, 5(2), 149-156. 